\title{
An Action Research Case Study of the Facilitators and Inhibitors
}

$$
\text { of E-Commerce Adoption }
$$

\author{
Orla Kirwan \\ NUI Galway, Ireland \\ Tel: 353-86-362-5057 E-mail: o.kirwan2@nuigalway.ie \\ Kieran Conboy (Corresponding Author) \\ Lecturer in Information Systems \\ NUI Galway, Ireland \\ Tel: 353-91-492-913Ｅ-mail: kieran.conboy@nuigalway.ie
}

\begin{abstract}
This research has studied an established Irish retail business as it takes its first tentative steps into the e-commerce arena. Although the adoption of e-commerce is widely studied in the academic world, only a small percentage of these studies focus on the Small to Medium size Enterprise (SME) retail sector. SMEs account for 97\% of Irish companies and employ up to 800,000 people (Chamber of Commerce Ireland, 2006). Whilst examining the SME's adoption of e-commerce, the factors that affected the adoption process were specifically identified and understood. This was achieved by conducting an action research case study. Action research merges research and practice thus producing exceedingly relevant research findings. The case study commenced in August 2003 and concluded in August 2004. It consisted of three distinctive action research cycles. The researcher worked in the SME throughout the research process, and had been employed there for the previous 5 years. This chapter demonstrates how the research was undertaken, and also discusses the justification, benefits and limitations of using action research. The research concluded that the adoption of e-commerce within the SME sector tends to be slow and fragmented, the presence of a "web champion" is paramount to the success of the project and Internet adoption is faster with the recognition of a business need. It also supported the evidence that an SME is more likely to adopt e-commerce when the SME owner has a positive attitude to IT.
\end{abstract}

Keywords: Action research, SME, E-commerce adoption, Internet

\section{Introduction}

Zwass (2003) defined e-commerce as "the sharing of business information, maintaining business information, and conducting business transactions by means of Internet-based technology". Figures released from Forrester Research reveal that e-commerce is surging (Forrester Research, 2006). In the US, online sales for the second quarter of 2005 reached nearly $\$ 39$ billion, a $25 \%$ year-over-year increase and a slight bump up from first quarter sales of $\$ 38$ billion. Total online sales in Europe will top $\$ 100$ billion this year; this represents a $21 \%$ increase over 2005 (Forrester Research, 2006). EBay has already seen its European sales volume soar $85 \%$ in the past year.

Internet adoption by SMEs is important to the generation of critical mass for e-commerce. While research has shown that SMEs are adopting the Internet and e-commerce (Coltman et al, 2001: Levy et al, 2001: Scupola, 2002), there is little systematic research into how such companies are adopting e-commerce. Egan et al (2003) recognized the need for such research: "More work with SME owners might usefully address a method for overcoming e-commerce adoption barriers; this research would be very useful if done in an action research mode". In answer to Egan's call, and in recognition of the important role that SMEs play in the Irish economy, the overall objectives of the study are to identify the factors that facilitate or inhibit e-commerce adoption in an Irish SME, and to understand how these factors affect the e-commerce adoption process.

\section{Literature Review}

SMEs are an important sector of any economy as they contribute to economic growth, social cohesion, and employment as well as regional and local development (Scupola, 2002). The European Union (EU) has 18 million SMEs, which are responsible for $67 \%$ of overall employment and $59 \%$ of GDP (Ritchie \& Brindley, 2005). 
A Forfás study in 1999 found that $99.4 \%$ of enterprises in Ireland are SMEs, and that they account for just under half of total enterprise employment in Ireland. Therefore, significant opportunities exist for the Irish SME sector to create efficiencies in communications, shift the trading power balance in its favour and create new markets (Egan et al, 2003). There has also been an increasing interest in the role and contribution of SMEs for the development and sustainability of a knowledge based economy in Ireland.

\subsection{E-Commerce and SMEs}

Traditionally, SMEs are lacking in resources, such as time and money (Levy et al, 2001). For this reason, they are relatively late adopters of new technology, and tend to adopt a "wait and see" attitude to e-commerce adoption (Forfás Report, 2002).

Forfás (2002), an Irish research agency, found that in Ireland 81\% of Irish SMEs have Internet access and $46 \%$ of the companies surveyed had a web site. E-commerce is widely argued to have the potential to transform the marketplace, and to provide SMEs with a wider variety of opportunities to engage in business activities (Levy et al, 2001).

For the last number of years the Internet and e-commerce have been offering exciting new competitive opportunities for SMEs to extend their customer base into the global marketplace, and broaden their involvement into new markets (Lewis and Cockrill, 2002).

Internet adoption by small businesses is important to the generation of critical mass for Internet commerce (Poon and Swatman, 1999). E-commerce is likely to have the most fundamental impact on SMEs by offering tremendous opportunities to high growth SMEs, but successive research studies have shown that significant business benefits are not being realized (Poon and Swatman, 1999, Levy and Powell, 2000). The literature states that there is little evidence that SMEs do more than develop websites and adopt e-mail (Levy and Powell, 2000).

\subsection{Factors Affecting the Decision to adopt E-commerce}

A decision to adopt e-commerce is not taken lightly, especially when the organisation is an SME. There are a variety of factors that facilitate or inhibit the adoption of e-commerce, and also several factors that could be classified as either a facilitator or an inhibitor, depending on the situation of the SME at that time. These factors need to be addressed prior to the decision to adopt e-commerce being made. These factors are outlined below in Table 1 .

\section{Research methodology}

This study is concerned with the factors that inhibit or facilitate Internet adoption within an Irish SME context, and also to understand how these factors affected the e-commerce adoption process. This was achieved by conducting an action research study on River Deep Mountain High (RDMH), Galway. RDMH is a retail SME based in Galway. The shop has specialised in outdoor clothing and equipment since 1991. RDMH expanded in 1995, opening a second branch in Limerick. Including both shops, there are a total of 20 employees. The researcher worked in the SME throughout the research process, and had been employed there for the previous 5 years. At the time of the research, there was no web site and hence, no e-commerce or e-business capabilities. The SME was in the process of adopting e-commerce, making it a highly suitable SME in which to conduct the proposed research. In order to increase awareness of the shop and hopefully expand the business, the company was moving to having an online presence, with a view to online shopping facilities in 3 years time. The research took place from August 2003 until August 2004, and it involved 3 distinct Action Research cycles, as outlined in figure 1 below.

\subsection{Benefits of using Action Research}

The following paragraph outlines the benefits of using action research as a research methodology. The high involvement of the researcher with the research subjects allows for access to rich and in-depth research data. Researchers can overcome the problem of trying to understand the ill-structured, fuzzy world of complex organizations by applying action research, as it addresses real-life problems and the immediate concerns of practitioners (Avison et al, 1999). Since the topic of the research is partly selected by the client (e.g. a company in a specific industry), its findings are likely to be of high relevance to at least a section of the practitioner community (e.g. the immediate research client and other companies in the same industry). The real world orientation of the approach offers a singular opportunity to recruit students who hold positions in organizations facing a problem whose solution can lead to relevant research findings. The problem-solving orientation of the research increases chances of obtaining research funding. Action research is usually participative. This implies a partnership between the researcher and the client. This approach may be deemed more satisfying and also more occupationally relevant (McNiff, 2000). Westbrook (1995) presented action research as an approach that could overcome three deficiencies associated with "traditional research methods":

- It has broad relevance to practitioners;

- It is applicable to unstructured or integrative issues;

- It can contribute to theory. 


\subsection{Action Research and Information Systems (IS) research}

The discipline of IS seems to be a very appropriate field for the use of action research methods (Myers, 1999). IS is a highly applied field, almost vocational in nature. Action research methods are particularly clinical in nature, and place IS researchers in a 'helping-role' within the organizations that are being studied. It should not be surprising that action research is the 'touchstone of most good organizational development practice' and remains the primary methodology for the practice of organizational development.

Action research is one of several qualitative research methods used in the field of IS' (Galliers, 1992). Such qualitative research is important for studying complex, multivariate, real-world phenomena that cannot be reduced for study with more positivist approaches (Baskerville \& Pries-Heje, 1999). Action research is especially important in situations where participation and organizational change processes are necessary (Baskerville \& Wood-Harper, 1996).

Given the frequent calls for IS research to be more relevant to practice (McTaggert, 1998; Rademacher, 2001), it is believed that action research has the potential to contribute to making IS research relevant. Action research merges research and practice thus producing exceedingly relevant research findings. Such relevance is an important measure of the significance of IS research.

\subsection{Justification of using Action Research in this study}

The researcher decided that action research was the preferred method for this research based on the factors listed in Table 2 below.

\subsection{Limitations of using Action Research}

Like most qualitative research methodologies, action research is difficult to do well and easier to do atrociously. Action research is much harder to report and the researcher also has to justify the overall approach. This has to be done well enough so that even if examiners do not agree with the approach, they have to acknowledge that the researcher has provided an adequate rationale. Action research involves heavy involvement in the research situation, with the opportunity for good learning, but at the potential cost of objectivity.

Table 3 below outlines how this research identified and addressed these possible limitations. This was undertaken to increase the credibility of the research findings.

\section{Findings}

\subsection{Factors affecting RDMH's e-commerce adoption process}

From the research, the following factors were identified as having affected RDMH's adoption process:

Perceived benefits: It was reported in section 2.2 that the recognition of perceived benefits by an SME will facilitate the e-commerce adoption process. These findings are consistent with the literature review as both the SME owner and the researcher felt that there were perceived benefits available from adopting e-commerce.

Web champion: The literature on e-commerce adoption has emphasized the importance of a "corporate champion" often identified as the owner/manager of an SME (Scupola, 2002; Poon and Swatman, 1999; Fink, 1998; Cragg and King, 1993). The "web champion" in the case of RDMH was the researcher, not the SME owner, who initiated and completed the e-commerce site. These findings are consistent with the literature, as the literature states that this role may or may not be assumed by the owner, and also the process of e-commerce adoption will be facilitated by the presence of one.

Organizational skills: The level of knowledge among IT and non-IT professionals is important in the e-commerce adoption process (Scupola, 2002; Mehrtens et al, 2001; Fink, 1998). Organizations with more IT experience or greater IT already in use are more likely to adopt IT (Fink, 1998). The findings from RDMH are consistent with this, as the researcher was employed by the organization and completing a Masters Degree in e-commerce at the same time. The SME owner had also computerized all of the stock in both branches of RDMH, and so is knowledgeable about IT and has a positive attitude to IS/IT.

Lack of time and resources: SMEs lack the willingness to dedicate the time and resources necessary to resolve their lack of understanding and skills (Chapman et al, 2000; Lewis and Cockrill, 2002). The researcher experienced a significant lack of time during the project. This was due to the fact that the researcher continued to work on the shop floor, as well as developing the website. This is consistent with the literature as RDMH is a typical SME.

Lack of understanding: The lack of understanding of the need to adopt innovations, such as ICT and e-commerce, prevents SMEs using them to overcome existing performance gaps or exploit new opportunities (Chapman et al, 2000). Again, this is similar to above and consistent with the literature. The researcher also lacked some understanding of the new technologies being used in the adoption process.

External pressures: There is little evidence of business strategy driving Internet adoption among SMEs. However, Internet adoption is faster when SMEs recognize a business need (Levy and Powell, 2003). The SME owner did not feel 
that it was a business need, therefore there was nothing done to adopt or develop a website for the shop until the researcher approached with the research proposal. This is consistent with the literature findings.

\subsection{How the factors actually affected RDMH's adoption process?}

As is evident, not all of the factors listed in table 1 were deemed relevant in the context of RDMH. Why were only six out of the thirteen possible factors listed as relevant? It was found that some were not applicable due to the nature of the website (front-end, information only). Others were not applicable due to the researcher embracing the role of web champion, and not the SME owner. Finally, others were not relevant due to the present state of the SME involved (financial situation, level of IT already adopted and future strategic expectations of having an online presence). See table 4 below for an explanation of how the factors identified were actually relevant.

\section{Conclusions}

This research has investigated the process that RDMH went through in order to add a website to the organization. After analyzing an SME that has moved from offline to online, a number of similarities and differences from the literature have been identified. The following conclusions have been drawn from the findings of this research.

\subsection{Conclusions regarding the e-commerce adoption process}

This research supports Poon and Swatman's (1999), and Levy and Powell's (2000) evidence that the adoption of IS/IT tends to be slow, fragmented and occurs in stages. In addition, this research confirms Levy et al's concept that most SME's will pursue a business strategy in which a company combines online e-commerce with a traditional retail outlet.

This research also supports Mehrtens et al's (2001) and Levy and Powell's (2003) research evidence that an SME that is likely to adopt e-commerce will most often have an owner who has a positive attitude towards IT adoption, who is innovative and who is knowledgeable about IT. The literature also emphasized the importance of a "corporate champion" often identified as the owner/manager of an SME (Scupola, 2002; Poon and Swatman, 1999; Fink, 1998; Cragg and King, 1993).

Most SMEs will find that web technologies will not be one of their core competences (Riemenschneider, 1999). This is not consistent with the findings, as the researcher was employed by the SME whilst concurrently pursuing a Masters Degree in e-commerce.

\subsection{Conclusions regarding the use of action research as a methodology}

From the research methodology perspective, the researcher encountered a number of difficulties that are well documented limitations of using action research. This included a significantly longer case study chapter, due to the need to present and analyze the three action research cycles in detail. The findings chapter was also quite complex as each issue needed to consider the researchers view, the SME owners view, and the final amalgamation of the two. This was overcome by eventually splitting the findings chapter into two separate components.

The degree of documentation was also high as the researcher maintained a journal throughout the adoption process, and each meeting was recorded in detail. As a result, the researcher had a significant amount of data to analyze. The researcher also had to ensure that when reflecting on the data, perceptions and interpretations were non-biased and accurate.

The benefits from having undertaken the research using this methodology included an increased depth of knowledge about the research process. Also, the extra depth, documentation and analysis were rewarded through what the researcher believes were more credible research findings. The researcher learnt some valuable lessons regarding the research process. Action research incorporated a significant amount of extra work for the researcher, a point that was raised by the supervisor at the start of the study. However, the researcher feels that the extra work was rewarded as it resulted in richer and more credible findings.

\section{References}

Avison, D., Lau, F., Nielsen, P.A. \& Myers, M. (1999). Action Research. Communications of ACM (42:1), pages 94-97.

Baskerville, R. \& Wood-Harper, A.T (1996). A Critical Perspective on Action Research as a Method for Information Systems Research. Journal of Information Technology, Volume 11, Issue 4, pages 235-246.

Baskerville, R. \& Wood-Harper, A.T (1998). Diversity in Information Systems Action Research Methods. European Journal of Information Systems (7:2), pages 90-107.

Baskerville, R. \& Pries-Heje, J. (1999). Grounded action research: a method for understanding IT in practice. Accounting, Management and Information Technologies, Issue 9, pages 1-23.

Chambers of Commerce (2006). www.chambers.ie. Accessed $12^{\text {th }}$ Dec 2006.

Chapman, P., James-Moore, J., Szczygiel, M. \& Thompson, D. (2000). Building Internet Capabilities in SME's. Logistics Information Management, 2000, Volume 13, Number 6, 353-361. 
Coghlan, D. \& Brannick, T. (2001). Doing Action Research in Your Own Organization. Sage Publications.

Coltman, T., Devinney, T., Latukefu, A. \& Midgley, D. (2001). E-Business: Revolution, Evolution or Hype? California Management Review, Volume 44, Number 1, 57-85.

Cragg, P. \& King, M. (1993). Small-Firm Computing: Motivators and Inhibitors. MIS Quarterly, Mar 1993, Vol. 17, Issue 1, 47-61.

Daniel, E. \& Grimshaw, D. (2002). An exploratory comparison of electronic commerce adoption in large and small enterprises. Journal of Information Technology, 2000, 17, 133-147.

Daniel, E., Wilson, H. \& Myers, A. (2002). Adoption of E-Commerce by SME's in the UK. International Small Business Journal, 2002, Volume 20 (3), 253-270.

Egan, T., Clancy, S. \& O Toole, T. (2003). The integration of e-commerce tools into the business processes of SMEs. Irish Journal of Management, Volume 24, Issue 1, 139-154.

Fink, D. (1998). Guidelines for the Successful Adoption of Information Technology in Small and Medium Enterprises. International Journal of Information Management, 1998, Volume 18, Number 4, 243-253.

Forfás (2002). "ebusiness, Where we are and Where do we go from here?" 1999.

Forrester Research (2006). Europe's eCommerce Forecast: 2006-2010. June 29, 2006

Galliers, R. (1992). Information Systems Research Issues, Methods and Practical Guidelines. Blackwell Scientific Publications.

Greenwood, D. \& Levin, M. (1998). Introduction To Action Research. Sage Publications.

Levy, M. \& Powell, P. (2000). Information systems strategy for small and medium sized enterprises: an organizational perspective. Journal of Strategic Information Systems, 9, 2000, 63-84.

Levy, M. \& Powell, P. (2003). Exploring SME Internet adoption: towards a Transporter model. Electronic Markets, Volume 13, Issue 2, Pages 171-181.

Levy, M., Powell, P. \& Yetton, P. (2001). SME's: aligning IS and the strategic context. Journal of Information Technology, 2001, 16, 133-144.

Lewis, R. \& Cockrill, A. (2002). Going global-remaining local: the impact of e-commerce on small retail firms in Wales. International Journal of Information Management, Volume 22, Issue 3, 2002, 195-209.

McNiff, J. (2000). Action Research in Organizations. Routledge, London.

McTaggart, R. (1998). Is validity really an issue for participatory action research? Studies in cultures, organizations \& societies, Volume 4, Issue 2, pages 211-237.

Mehretens, J., Cragg, P. \& Mills, A. (2001). A Model of Internet adoption by SME's. Information \& Management, Issue 39, 2001, 165-176.

Min, H. \& Galle, W. (2001). Electronic Commerce-based Purchasing: A Survey on the Perpetual Differences Between Large and Small Organizations. International Journal of Logistics, Volume 4, Issue 1, April 2001, 79-96.

Myers, M. (1997). Qualitative Research in Information systems. MIS Quarterly, Volume 21, Issue 2, pages 241-243.

Poon, S. \& Swatman, P. (1999). An exploratory study of small business Internet issues. Information \& Management, Volume 35, Issue 1, Jan 1999, 9-18.

Rademacher, R. (2001). The Changing Profile of Information Systems Research: 1995-2000. Journal of Computer Information Systems, Volume 42, Issue 1, pages 13-17.

Riemenschneider, C. \& McKinney, V. (1999). Assessing the Adoption of Web-based E-Commerce for Businesses. Electronic Markets, Volume 9 (1/2), 9-13.

Ritchie, B. \& Brindley, C. (2005). ICT adoption by SMEs: implications for relationships and management. Work \& Employment, Volume 20, Issue 3, pages 205-217.

Scott, M. Golden, W. \& Hughes, M. (2003). E-Tailing in Ireland: A review of Ireland's top 25 retailers. Irish Marketing Review, Volume 16, Issue 1, 15-24.

Scupola, A. (2002). Adoption issues of B2B Internet commerce in European SMEs. Proceedings of the $35^{\text {th }}$ Hawaii International Conference on Systems Science, 2002.

Susman, G. \& Evered, R. (1978). An assessment of the scientific merits of action research. Administrative Science Quarterly, 23(4), pages 582-603. 
Westbrook, R. (1995). Action research, a new paradigm for research on production and operations management. International Journal of Operations and Production Management, Volume 15, Number 12, pages 6-20.

Wymer, S. \& Regan., E. (2006). Factors Influencing e-commerce Adoption and Use by Small and Medium Businesses. Electronic Markets, Vol. 15, Issue 4, pages 438-453.

Zwass, V. (2003). Electronic Commerce and Organizational Innovation: Aspects and Opportunities. International Journal of Electronic Commerce, Volume 7, Number 3, 2003, 7-37.

Table 1. Factors Affecting the Decision to adopt E-commerce

\begin{tabular}{|c|c|c|}
\hline Factor & Reference & Facilitator/ Inhibitor \\
\hline Perceived Benefits & $\begin{array}{l}\text { Poon and Swatman (1999) found that perceived benefits were a key } \\
\text { reason why participants adopted and continued to use the Internet. }\end{array}$ & Facilitator \\
\hline Business Need & $\begin{array}{l}\text { There is little evidence of business strategy driving Internet adoption } \\
\text { among SMEs. However, Internet adoption is faster when SMEs } \\
\text { recognize a business need (Levy and Powell, 2003). }\end{array}$ & Facilitator \\
\hline $\begin{array}{l}\text { Owner/Manager } \\
\text { Influence }\end{array}$ & $\begin{array}{l}\text { The literature on e-commerce adoption has emphasized the importance } \\
\text { of a "corporate champion" often identified as the owner/manager of an } \\
\text { SME (Scupola, 2002; Poon and Swatman, 1999; Fink, 1998; Cragg and } \\
\text { King, 1993). An SME that is likely to adopt e-commerce will most } \\
\text { often have an owner who has a positive attitude towards IT (Mehrtens et } \\
\text { al, 2001; Levy and Powell, 2003). }\end{array}$ & Either \\
\hline Web Champion & $\begin{array}{l}\text { The web champion or "corporate champion" may or may not be the } \\
\text { SME owner. In some cases, it is an internal member of staff. }\end{array}$ & Facilitator \\
\hline Organizational Structure & $\begin{array}{l}\text { For most SMEs, their failure to plan the introduction and exploitation of } \\
\text { new technology is due to management limitations (Levy et al, 2001). } \\
\text { Min and Galle (2001) found that organization size is believed to } \\
\text { influence the e-commerce adoption practices of firms. }\end{array}$ & Either \\
\hline Organizational readiness & $\begin{array}{l}\text { This is the extent to which an organization feels ready to adopt } \\
\text { e-commerce (Fink, 1998; Scupola, 2002). Among the factors that } \\
\text { determine this are: skills and knowledge of the technology, internal IT } \\
\text { support and support from external parties such as IT vendors (Chapman } \\
\text { et al, 2000; Mehrtens et al, 2001; Scupola, 2002). }\end{array}$ & Either \\
\hline $\begin{array}{l}\text { Organizational } \\
\text { Skills }\end{array}$ & $\begin{array}{l}\text { E-commerce imposes new skills requirements on the retail sector } \\
\text { (Lewis and Cockrill, 2002). The successful uptake of e-commerce } \\
\text { requires IT expertise, coupled with strong business applications skills } \\
\text { and therefore a flexible, multi-skilled work force is required (Lewis and } \\
\text { Cockrill, 2002). }\end{array}$ & Either \\
\hline $\begin{array}{l}\text { Lack of time and } \\
\text { resources }\end{array}$ & $\begin{array}{l}\text { SMEs lack the willingness to dedicate the time and resources necessary } \\
\text { to resolve their lack of understanding and skills (Chapman et al, 2000; } \\
\text { Lewis and Cockrill, 2002). These resources involved are human, } \\
\text { financial and time. SMEs are regarded as "poor" in human, financial } \\
\text { and material resources (Levy et al, 2001). }\end{array}$ & Inhibitor \\
\hline $\begin{array}{l}\text { Lack of } \\
\text { Understanding }\end{array}$ & $\begin{array}{l}\text { The lack of understanding of the need to adopt innovations, such as ICT } \\
\text { and e-commerce, prevents SMEs using them to overcome existing } \\
\text { performance gaps or exploit new opportunities (Chapman et al, 2000). }\end{array}$ & Inhibitor \\
\hline Cost Factors & $\begin{array}{l}\text { Strategically, information systems are used in order to lower the costs of } \\
\text { production, coordination and transactions or to add value to the product, } \\
\text { process or service (Levy et al, 2001). As the cost of IS falls, SME's are } \\
\text { starting to reap the benefits of these systems, as they are more } \\
\text { accessible (Levy et al, 2001). Yet, the tendency in SME's is still to view } \\
\text { IS investment as a cost (Levy and Powell, 2000; Wymer \& Regan, } \\
\text { 2006). }\end{array}$ & Either \\
\hline
\end{tabular}




\begin{tabular}{|l|l|l|l|}
\hline Government Initiatives & $\begin{array}{l}\text { The Irish Government has enacted a number of critical Acts to underpin } \\
\text { eBusiness development including the Electronic Commerce Act 2000, } \\
\text { the Copyright and Related Rights Act } 2000 \text { and the Communications } \\
\text { Regulation Act 2002. Ireland has made major investments in national } \\
\text { information infrastructures, including international telecommunications } \\
\text { connectivity, Internet data centres and other support services }\end{array}$ & Facilitator \\
\hline Security Concerns & $\begin{array}{l}\text { Daniel at al (2002) reported that the concern about security was } \\
\text { inhibiting adoption, as were lack of customer satisfaction and use. In a }\end{array}$ & Inhibitor \\
& $\begin{array}{l}\text { 2001 report by the Chamber of Commerce Ireland, it was reported that } \\
34 \% \text { of businesses felt that concerns about security were an obstacle in } \\
\text { their path to e-business (Scott et al, 2003). }\end{array}$ & \\
\hline External & $\begin{array}{l}\text { This pressure comes from existing Internet users, particularly customers } \\
\text { and competitors, but also suppliers and potential employees (Mehrtens } \\
\text { Pressure/External }\end{array}$ & et al, 2001; Daniel et al, 2002; Cragg and King, 1993). & Either \\
Environment & \multicolumn{2}{|l}{} & \\
\hline
\end{tabular}

Table 2. Factors influencing research methodology

\begin{tabular}{|c|c|}
\hline $\begin{array}{l}\text { Factor influencing research } \\
\text { methodology }\end{array}$ & Reason for Influence \\
\hline $\begin{array}{l}\text { There is a unique opportunity } \\
\text { available to the researcher to } \\
\text { conduct the research in a } \\
\text { dynamic SME environment. }\end{array}$ & $\begin{array}{l}\text { The SME involved, RDMH, was at that time initiating the process of e-commerce } \\
\text { adoption. The researcher was employed there, and had been for five years, and also had } \\
\text { full access to the SME. }\end{array}$ \\
\hline $\begin{array}{l}\text { In this case, the researcher is } \\
\text { solely responsible for the } \\
\text { e-commerce implementation } \\
\text { process. }\end{array}$ & $\begin{array}{l}\text { The RDMH management had very limited participation. Action research is a research } \\
\text { method that solves immediate practical problems while expanding scientific knowledge } \\
\text { (Avison, et al., 1999). }\end{array}$ \\
\hline $\begin{array}{l}\text { High suitability to the research } \\
\text { topic and to how the research } \\
\text { will be carried out. }\end{array}$ & $\begin{array}{l}\text { Egan et al (2003) recognized the need for such research: "More work with SME owners } \\
\text { might usefully address a method for overcoming e-commerce adoption barriers; this } \\
\text { research would be very useful if done in an action research mode". }\end{array}$ \\
\hline $\begin{array}{l}\text { As the research area is } \\
\text { concerned with rich, subjective, } \\
\text { qualitative data, not quantitative } \\
\text { data, the research philosophy is } \\
\text { interpretivist in nature. }\end{array}$ & $\begin{array}{l}\text { Action research tends to be both participative and qualitative. The virtue of action } \\
\text { research is in its responsiveness to the research situation (Greenwood and Levin, 1998). } \\
\text { One of the key principles of action research is: let the data decide. At each step of the } \\
\text { process, the information collected so far will determine the next step of the process. }\end{array}$ \\
\hline $\begin{array}{l}\text { The research approach will be } \\
\text { inductive. }\end{array}$ & This \\
\hline $\begin{array}{l}\text { The research situation demands } \\
\text { responsiveness during the } \\
\text { research project as the research } \\
\text { occurs in a changing } \\
\text { environment in real-time. }\end{array}$ & $\begin{array}{l}\text { Action research is appropriate when the research question relates to describing an } \\
\text { unfolding series of actions over time in a given group, community or organization; } \\
\text { understanding as a member of a group how and why their action can change or improve } \\
\text { the working of some aspects of a system; and understanding the process of change or } \\
\text { improvement in order to learn from it (Coghlan \& Brannick, 2001). The proposed } \\
\text { research in RDMH, where the strategic focus of the SME is short-term and is therefore in } \\
\text { a constant state of flux, makes action research suitable for this research. }\end{array}$ \\
\hline $\begin{array}{l}\text { Participation of researcher in the } \\
\text { research environment. }\end{array}$ & $\begin{array}{l}\text { One of the reasons for the emergence of action research and its subsequent use in the IS } \\
\text { field is the recognition, largely motivated by the early work of ethnographers, that a } \\
\text { research environment can be more deeply understood if the researcher becomes part of } \\
\text { that environment (McNiff, 2000). }\end{array}$ \\
\hline $\begin{array}{l}\text { The researcher serves two } \\
\text { masters. }\end{array}$ & $\begin{array}{l}\text { A key characteristic of action research sets it apart from other research approaches. In } \\
\text { action research, investigators try to fulfill the needs of their study subjects and, at the } \\
\text { same time, generate new knowledge. As such, IS action researchers have to serve two } \\
\text { masters: their immediate research clients, who directly benefit from the research while it } \\
\text { is being conducted, and the IS academic community in general. }\end{array}$ \\
\hline
\end{tabular}


Table 3. Limitations of using action research and how the researcher overcame these

\begin{tabular}{|c|c|c|}
\hline Possible limitations of AR & How to address the limitation & How this was achieved in the study of RDMH \\
\hline \multirow[t]{7}{*}{$\begin{array}{l}\text { Achieving rigour - way of } \\
\text { assuring the quality of the } \\
\text { data collected }\end{array}$} & $\begin{array}{l}\text { Use of action research cycles to } \\
\text { provide adequate iterations }\end{array}$ & $\begin{array}{l}\text { There were } 3 \text { definite action research cycles during the } \\
\text { collection of the results. Susman and Evered, two leading } \\
\text { authors in this field, advise the use of numerous action } \\
\text { research cycles within a given piece of research. }\end{array}$ \\
\hline & $\begin{array}{l}\text { Planning of methodical data } \\
\text { collection methods }\end{array}$ & $\begin{array}{l}\text { Interviews were used as the data collection method. The } \\
\text { researcher was careful not to influence the owner } \\
\text { regarding the answers, as this would increase researcher } \\
\text { bias. }\end{array}$ \\
\hline & $\begin{array}{l}\text { Careful nurturing of collaboration } \\
\text { with subjects }\end{array}$ & $\begin{array}{l}\text { The collaboration process with the owner began in } \\
\text { August 2003, with the establishment of the client-system } \\
\text { infrastructure, this collaboration continued throughout the } \\
\text { research process. }\end{array}$ \\
\hline & $\begin{array}{l}\text { Interpretations will be developed } \\
\text { as part of the data collections }\end{array}$ & $\begin{array}{l}\text { The researcher and owner developed interpretations on } \\
\text { the findings. This occurred when meeting to come to a } \\
\text { consensus on the results. }\end{array}$ \\
\hline & $\begin{array}{l}\text { The relevant literature will be } \\
\text { accessed as part of the } \\
\text { interpretation, to widen the } \\
\text { dialectic }\end{array}$ & $\begin{array}{l}\text { For the generation of each report for the SME owner, the } \\
\text { literature was accessed }\end{array}$ \\
\hline & $\begin{array}{l}\text { Multiple data sources will be } \\
\text { accessed to provide a dialectic }\end{array}$ & $\begin{array}{l}\text { For the findings, the primary sources of data were the } \\
\text { researcher and the SME owner. This was supplemented } \\
\text { by documentation and literature from the organisation, } \\
\text { and relevant academic literature. }\end{array}$ \\
\hline & $\begin{array}{l}\text { Establish an ethical client-system } \\
\text { infrastructure and research } \\
\text { environment }\end{array}$ & $\begin{array}{l}\text { This was established August 2003. It was agreed that the } \\
\text { SME would be used as the proposed research } \\
\text { environment, and it was also agreed that the researcher } \\
\text { would have unlimited access to the information and } \\
\text { documentation contained within the SME that was related } \\
\text { to the research project. }\end{array}$ \\
\hline $\begin{array}{l}\text { Validity }- \text { are the findings } \\
\text { really about what they appear } \\
\text { to be about? }\end{array}$ & $\begin{array}{l}\text { Conscious and deliberate } \\
\text { enactment of the action research } \\
\text { cycles }\end{array}$ & $\begin{array}{l}\text { Each stage of each action research cycle was followed } \\
\text { with deliberate purpose, and each stage was adhered to } \\
\text { correctly according to the academic research that was } \\
\text { carried out on the action research cycles. }\end{array}$ \\
\hline $\begin{array}{l}\text { Researcher bias / Lack of } \\
\text { impartiality }\end{array}$ & $\begin{array}{l}\text { Researcher needs to consider the } \\
\text { extent to which the story is a valid } \\
\text { presentation of what has taken } \\
\text { place }\end{array}$ & $\begin{array}{l}\text { The researcher was very careful not to prompt the SME } \\
\text { owner during the interviews, with respect to the } \\
\text { researcher's answers, as the researcher had already } \\
\text { independently answered the questions prior to } \\
\text { interviewing the owner. }\end{array}$ \\
\hline $\begin{array}{l}\text { Generalisability - the extent } \\
\text { to which the findings are } \\
\text { equally applicable in other } \\
\text { settings }\end{array}$ & $\begin{array}{l}\text { It will not be a problem if the } \\
\text { researcher does not claim that the } \\
\text { results, conclusions or theory can } \\
\text { be generalized. }\end{array}$ & $\begin{array}{l}\text { As SMEs tend to be industry specific, there is a lot of } \\
\text { diversity across the sectors. This study was concerned } \\
\text { with the retail sector. }\end{array}$ \\
\hline
\end{tabular}


Table 4. How the factors identified actually affected the adoption process.

\begin{tabular}{|c|c|c|}
\hline $\begin{array}{l}\text { Factor affecting the decision to } \\
\text { adopt }\end{array}$ & $\begin{array}{c}\text { Facilitated/ } \\
\text { Inhibited }\end{array}$ & How was it relevant? \\
\hline Perceived benefits & Facilitated & $\begin{array}{l}\text { These helped the SME owner to see some future benefit from } \\
\text { the project. It also helped to increase the owner's enthusiasm } \\
\text { for the website. }\end{array}$ \\
\hline Web champion & Facilitated & $\begin{array}{l}\text { All of the incentive for this website had come from the } \\
\text { researcher. This had started in August } 2003 \text { when the } \\
\text { researcher approached the SME owner and proposed the } \\
\text { website development. }\end{array}$ \\
\hline Organisational skills & Facilitated & $\begin{array}{l}\text { The researcher was employed by the organisation, so the } \\
\text { skills that the researcher had as a result of the } 1^{\text {st }} \text { year of the } \\
\text { MBS programme benefited the SME. }\end{array}$ \\
\hline Lack of time and resources & Inhibited & $\begin{array}{l}\text { The researcher worked in the shop and developed the } \\
\text { website, and as a result, experienced a serious time shortage } \\
\text { during the day trying to balance both activities. }\end{array}$ \\
\hline Lack of understanding & Inhibited & $\begin{array}{l}\text { The researcher spent extra time on the development of the } \\
\text { site, as it was the first time using the software involved, } \\
\text { Dreamweaver MX. }\end{array}$ \\
\hline External pressures & Inhibited & $\begin{array}{l}\text { The researcher saw that customers were ready for the } \\
\text { website, having been asked at different times over the } \\
\text { previous three years, if the company had one or not. The } \\
\text { SME owner did not agree in this instance, as a lack of a } \\
\text { business was stated as the reason why the organisation had } \\
\text { not previously gone online. }\end{array}$ \\
\hline $\begin{array}{l}\text { Role of the SME owner } \\
\text { This factor did affect the adoption } \\
\text { process, although there was conflict } \\
\text { between the researcher and the SME } \\
\text { owner when agreeing on the role that } \\
\text { it played. }\end{array}$ & Facilitated & $\begin{array}{l}\text { The research has shown that the owner had a very positive } \\
\text { attitude to IS/IT adoption as when the researcher approached } \\
\text { the owner with the website proposal, the owner agreed to the } \\
\text { suggestion immediately. The owner's positive attitude } \\
\text { facilitated the adoption of e-commerce, even though it was } \\
\text { stated that the owner did not see the website as a business } \\
\text { need. }\end{array}$ \\
\hline $\begin{array}{l}\text { Cost factors } \\
\text { Again, this factor did affect the } \\
\text { adoption process, although there was } \\
\text { conflict between the researcher and } \\
\text { the SME owner when agreeing on } \\
\text { the role that it played }\end{array}$ & Inhibited & $\begin{array}{l}\text { Initially, the owner did not feel that cost was an issue as the } \\
\text { researcher was completing it in-house. In reality, cost was the } \\
\text { deciding factor of the type of web site that would be adopted } \\
\text { and developed. The owner perceived the development of the } \\
\text { website as free until the } 1^{\text {st }} \text { report was studied. It was then } \\
\text { decided to adopt a front-end, information only site with no } \\
\text { online sale capabilities, as the researcher could develop it } \\
\text { in-house at no extra cost. This is consistent with the } \\
\text { literature findings as the tendency in SME's is still to view IS } \\
\text { investment as a cost (Levy and Powell, 2000; Wymer \& } \\
\text { Regan, 2006). }\end{array}$ \\
\hline
\end{tabular}

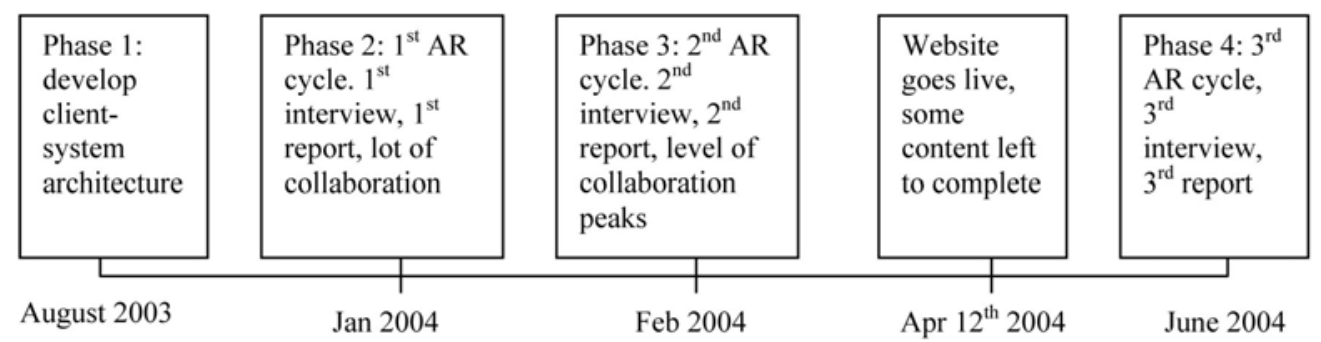

Figure 1. Timeline of RDMH's research framework 